\title{
A PERSPECTIVE OF RIVER BASIN DEVELOPMENT**
}

\author{
GILBERT F. White $\dagger$ \\ I \\ INTRODUCTION
}

The river systems of the world flow today with only a small proportion of their total volume harnessed and applied for human good. With the exception of a few small drainage basins in arid regions, the water of no stream has been fully regulated or used. There are physical limits to such regulation and use, but the degree to which those limits are approached is related to conditions which are partly technological, partly economic, partly political, and partly ethical.

Using the concept of integrated river basin development, each major network of streams draining the land masses of the earth may be viewed as the backbone for a possible planned use of a unified system of multiple-purpose and related projects to promote regional growth. This view of river basin development has come, during the past sixty years, to be employed rather widely as a technical tool for achieving social change. It has found imaginative support, and it appears to be on the threshold of wider application. How much further it wisely may be applied would seem to depend, in part, upon sharpening of our knowledge as to its utility and implications as a tool. Like any tool, it is not inherently good. Its value must be judged in terms of the growth and changes it can effect and upon its flexibility and precision.

The concept of river basin development is used here to mean three component ideas having separate roots in western civilization but coming to be associated with each other in present-day theory and practice. In addition, at least two other ideas have been related in varying circumstances, and it now is possible to suggest a definition of the tool on which there is relatively common agreement in practice.

Before examining the evolution of that concept, it may be helpful to identify the broad limits to river basin development and the distinguishing characteristics of river systems.

\section{A. Limits and Degrees of Development}

Although the Nile and Tigris-Euphrates Valleys cradled the early civilizations of the eastern Mediterranean and still support their basic irrigation agriculture, and although the flows of the Rhine, the Ohio, and the Thames long have been essential to the industrialized populations along their banks, it would be inaccurate to regard

* The author is indebted to Edward A. Ackerman for helpful criticism of the manuscript.

† S.B. 1932, S.M. 1934, Ph.D. 1942, University of Chicago. Professor of Geography, University of Chicago. Formerly geographer with Mississippi Valley Committee, National Resources Committee, and National Resources Planning Board; member of Task Force on Natural Resources of first Hoover Commission; member of President's Water Resources Policy Commission. Author, Human Adjustment to FLoods (1942). 
any of them as having attained a high degree of development by contemporary standards of river regulation. Development implies at least two physical changes in stream flow. One is the regulation of flow by storage, diversion, or land management so that the water is available when and where needed, rather than as dictated by natural fluctuations over days, seasons, and years. The other is the use of the water to maximize returns from other resource use. Under this definition, no stream can be considered fully developed unless, over long periods, its flow has been so regulated as completely to serve whatever purposes can, on grounds of social needs and economic growth, be shown to be important to the society involved. Only a few drainage basins are free from annual periods of water deficiency. ${ }^{1}$ The ideally regulated stream would fluctuate in its main channels only to meet fluctuating human demands, the natural variations having been evened out.

The engineering means-dams, diversion canals, water-spreading devices-are available to carry out such regulation in most, but not all, situations. In some areas, because of special conditions, such as unstable foundations in deltas, no engineering solution is known to problems of controlling river flow.

Whether or not regulation is possible under prevailing technology, however, the physical limits to such regulation may be estimated with modest accuracy. For example, the total amount of electric power which a stream is capable of generating may be calculated: the amount of power is a function of volume of natural flow, fall, and regulation. It is possible, as well, to calculate the total acreage of land which may be irrigated from a stream, if fully regulated, taking into account the consumptive use made by different assumed crops and cropping practices. The consumptive use of water by animal and human populations also may be computed, but such uses are only a small proportion of the water withdrawn for rural and urban purposes. Typically, more than ninety per cent of water employed in a municipal system is used nonconsumptively - that is, returned to a stream or aquifer, but with some change in chemical quality. The theoretical limit to the amount of nonconsumptive use for urban purposes is very high, so long as appropriate means of purification, waste treatment, and recycling are assumed to be available. Similar considerations apply to the use of water for navigation, wildlife, and recreational purposes, although in those cases, the loss of water by evaporation from reservoir and stream surfaces or by transpiration from plants may be heavy.

Every stream, accordingly, has a definite maximum potential output of hydroelectric power and maximum possible consumptive use of water. But the use which is made within those limits depends upon the complex interworking of factors affecting the particular technologies and uses which will be employed. For example, the decision to generate electric power at a given site is influenced by the engineering feasibility of alternative designs, costs of construction, alternative means of generating power, opportunities for marketing, availability of capital, investment alternatives,

${ }^{1} \mathrm{~A}$ basin may have a large stream flow and still suffer a deficiency of water for crop or processing needs. The amount and duration of this deficiency in humid areas is greater than is commonly recognized. See C. W. Thommiwatte and J. R. Mather, The Water Barance (x956). 
availability of labor force, accessibility of construction materials, and organization to plan and carry out the project. These and other factors will be discussed elsewhere in this symposium. It is important here only to note that the degree to which the ideals of full regulation and full use are approached is a function of those factors.

Thus, the actual accomplishment in the Nile or the Tigris-Euphrates or the Rhine falls far short of full regulation or full use. Several lower right-bank tributaries of the Rhine probably are more nearly regulated and used than any other humid or subhumid drainage area. A population of approximately 4,700,000 gains its livelihood from mining, heavy industry, and associated activities in a drainage area of 5,437 square miles. The waters of the Emscher, Lippe, Ruhr, and Wupper are handled by an intricate system of works, including storage reservoirs, diversion tunnels, collection sewers, city and industrial waste-treatment plants, channel improvements, pumping plants, channel dams, and hydroelectric installations. Water from one channel reservoir is pumped back to the upper reservoir at night to serve again during the daytime, and in periods of low flow, the water may be used several times. The responsible authorities are, however, looking forward to much more intensive development. $^{2}$ The physical limits of development are being approached, but they have not been reached.

The exceptions-the streams with more nearly complete regulation and use-are those, such as the upper Salt, in Arizona, where the storage structure in an area of heavy and chronic water deficiency halts all flood flows and fails to yield enough reliable supply to meet irrigation commitments.

What is true on a small scale for these highly developed tributaries is true on a vast scale for the major drainage basins of the world. Even the Tennessee is not completely developed. While its main navigation channel has been assured and an intricate system of reservoir regulation has been perfected, it still could have a flood high enough to damage low-lying portions of Chattanooga, and the planned management of some tributaries has only begun. The great rivers typically have flood peaks which reach the sea unused, leaving behind a muddy trail of damage. Their low flows still hinder economic life in times of unusual drought. In many of them, fruitful uses are precluded by lack of regulation or by unsatisfactory bacterial or chemical quality. The gap between what is technically attainable and what exists is everywhere large, although smaller in a few streams of Europe, Asia, and the United States than elsewhere. There seems little doubt that in every basin of more than 2000 square miles drainage area and in many smaller ones, there is the physical possibility of evening out flow by further storage, of decreasing the pollution of waters, and of readjusting upstream land use so as to reduce unnecessary soil loss and make wiser use of water. The social feasibility of such water and land management is, of course, a separate problem.

\footnotetext{
'See Pruss, Wasserversorgung und Abwasserbeseitigung im Ruhrgebiet auf genossenschaftlicher Grund. lage, in Ordnung und Planung IM RuHR, Raum 58 (I95I); Goepner, Die Wasserversorgung des rheinischwestfaelischen Industriegebeits, in GeOGaphisches TAsCHENBUGH 306 (1956).
} 
Before generalizing further about either the idea or the practice of river development, however, it is in order to offer a word of caution as to rivers themselves.

\section{B. No Two Rivers Are the Same}

If there is any conclusion that springs from a comparative study of river systems, it is that no two are the same. Each river is distinctive in characteristics of basin and flow. And rare are the streams that, regardless of size, are homogeneous within their own drainage areas.

The essential elements in a stream system are the river channels, the soils and aquifers by which water reaches the channels, and the flowing water itself. At any one time, the channel section, the contributing slopes and aquifers, and the stream flow bear definite, but not fully measured, relationships to each other, and these relationships change as the volume and quality of water in the stream change. For a true picture of a river, it thus is necessary to describe not only its condition at a given time, but its changes from day to day, from season to season, and from year to year. It is possible to measure, for example, for any stream:

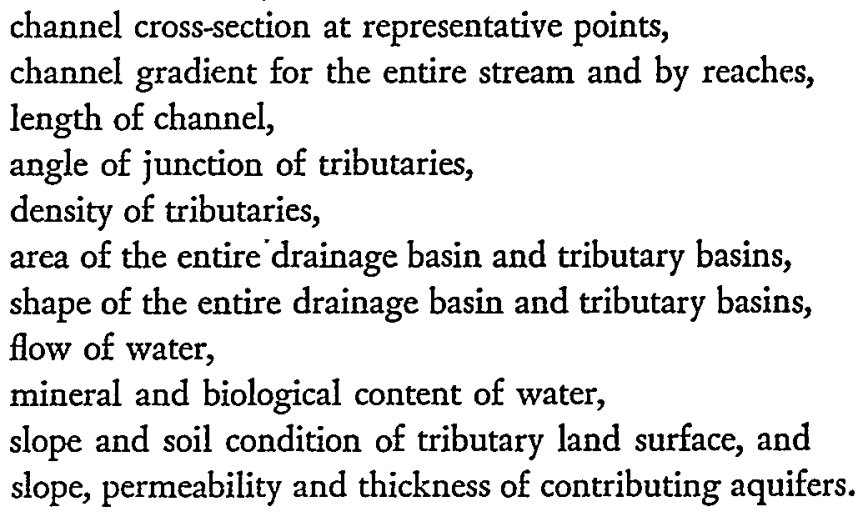

When any one of these characteristics is examined, an amazing range is found among the streams, and no two are found to be precisely the same. Adequate explanation of differences in flow behavior under different conditions of land use, for example, is complicated and is not entirely practicable in our present state of knowledge. Knowledge of origin and flow of sediment in suspension is even less complete.

The point here is that streams are unique combinations of natural features whose processes follow principles for the most part known. They cannot be regarded as interchangeable, and while they may be grouped into broad classes according to their combinations of characteristics, the planning of their development always involves a new, adventurous exploration for each stream, revealing differences in flow, channel, sediment, and chemical quality.

II

Central Ideas in River Basin Development

The concept of integrated river basin development, as it has come to be used by 
many scientists, engineers, and statesmen around the world today, seems to consist in three associated ideas. These are the ideas of the multiple-purpose storage project, the basin-wide program, and comprehensive regional development. They took shape over more than half a century, forming side by side, each drawing stimulus from a different set of conditions, but not clearly combining into single programs in the United States until the middle I930's. They still are far from finding full expression in many areas of water and land resources activity. Their combination is more an ideal than a reality, but it is an ideal which recurs in differing form so frequently and widely and which commands such warm enthusiasm as a symbol in public thinking that it should be reckoned with as a unit.

Others ideas have entered into the arena of public action, sometimes figuring prominently, and these also should be considered. The idea of articulated land and water programs is one such line of thought. The idea of unified basin administration is another. These are less persistent and influential in the work undertaken thus far, however, and appear to have played a secondary role. ${ }^{3}$ This review deals primarily with the United States, but it outlines some of the more influential changes in other countries.

One hundred years ago, Humphreys and Abbot, in making the first monumental survey of flood problems in the lower Mississippi Valley, could be comfortable in dismissing remedial reservoir work on tributaries as unimportant or relating only to low-water navigation and in limiting their detailed recommendations to the main stem of the river. ${ }^{4}$ Engineers for irrigation works in Egypt or India could feel warranted in putting forward single projects to serve single purposes. ${ }^{5}$ Whenever man was dealing with rivers, he was touching them at a particular point for a particular purpose and, with the exception of a few far-seeing men, like Powell and Willcocks, rarely dreamed of laboring with the whole river for multiple purposes.

By I900, however, three new ideas had begun to emerge and to receive discussion. They were slow in finding acceptance, and it was several decades before all had been

\footnotetext{
${ }^{3}$ Various definitions of the same general complex of ideas are current. The Bureau of Flood Control of the Economic Commission for Asia and the Far East uses "multiple-purpose river basin development" to include multiple-purpose use, unified development of entire basins, social benefits and costs applied to a region, comprehensive development of all resources, and unified control. Economic Comm'n FOR Asta and the Far East, Multiple-Purpose River Basin Development pt. I, at I-8 (U.N. Pub. Sales No. 1955.II.F.I). It draws, in part, from the report of the President's Water Resources Policy Commission, whose legal staff defined comprehensive development of water resources as "basin-wide development for optimum beneficial uses of a river system and its watershed." President's Water Resources Policy Comm'n, Water Resources LaW 383 (I950). A common variation is illustrated in Roy E. Huffman, Irrigation Development and Public Water Policy i53 (i953): “A comprehensive development program for a river valley involves working with three resources of equal importance-water, land and people. In the past, water has tended to receive major emphasis, while the other two factors played a minor role or were disregarded altogether in project and program formulation."

'A. A. Humpereys and H. L. Abbor, Report Upon the Physics and Hydraulics of the MissisSIPPI RIVER 406-II (2d ed. 1876). They considered, but dismissed as inapplicable, the plans of French and Italian engineers and of the Americans, Ellet and Morris, for reservoir systems.

E William Lumsden Strange, Indian Storage Reservoirs with Earthen Dams iv (ig04); and G. W. Macgeorge, Ways and Works in INDIA IO7-215, 43I-42 (I894).
} 
translated into action in an appropriate scale. Today, they still await a full and thorough demonstration in a single area.

\section{A. Multiple-Purpose Storage}

Hoover Dam, on the Colorado River, is a conspicuous example of a form of engineering design which uses a single structure to store water for multiple purposes. ${ }^{\circ}$ A concrete gravity dam, with a height of 726 feet and a mass of 3,250,000 cubic yards, it blocks the flow of the Colorado in the Black Canyon, providing sufficient storage and accompanying structure to assure that the flow can be fully controlled below that point to serve four major uses. The stored water may be diverted downstream to irrigate farms in the Imperial and Coachella Valleys of California. It also is diverted to serve the residential, agricultural, commercial, and manufacturing needs of Southern California to the extent of 1,500 cubic feet per minute. The water released through the dams is used to generate electric power, which is marketed as falling water to the states of Arizona and California and to the city of Los Angeles. A part of the reservoir storage, approximately 9,500,000 acre-feet, is reserved for the control of peak floods, so as to prevent them from traveling on downstream, where damage, chiefly to the Imperial Valley, might result from the river going over its banks. In addition to these four objects of irrigation, municipal water supply, hydroelectric power, and flood control, the dam was designed to help maintain a flow of water for navigation in the lower channel. Navigation has only theoretical importance, the theory, however, being a crucial one, in as much as the improvement of navigation formed the ostensible constitutional peg upon which federal action in undertaking a project of this magnitude first was hung.

Hoover Dam was authorized under the Boulder Canyon Project Act of ${ }^{9} 28{ }^{7}{ }^{7}$ upon the basis of an interstate compact first concluded by the states of the Colorado basin in $1922^{8}$ for the allocation of the waters of the basin, but it was not finally ratified with reservations by the requisite number of states, Arizona refraining, until I929. Its design had begun in preliminary form on the drafting tables of the Bureau of Reclamation engineers ten years earlier, when the first intensive studies were made of the possibility of harnessing the river, and they applied to a monumental problem the fruits of their experience with many smaller, less complicated river projects in the western states.

When Hoover Dam was authorized, there were in the world few conspicuous examples of a large multiple-purpose storage project. There were numerous projects at which two or three purposes were served, most of them not involving storage. The storage projects were chiefly in western Europe and western United States. In the Ruhr-Westfalian area, there was a series of seventeen smaller dams constructed around the turn of the century to store water for industrial and municipal supply, to gen-

'Sec Paul L. Kleinsorge, The Boulder Canyon Project (I94I).

${ }^{7} 45$ STAT. ro57, 43 U.S.C. \$6r7 (1952).

${ }^{8}$ Signed at Santa Fe, New Mexico, Nov. 24, I922, pursuant to Act of Aug. I9, I921, c. 72, 42 STAT. I7I, approved by Congress, Act of Dec. 2I, I928, c. 42, 45 STAT. I064, 43 U.S.C. S6I7l (I952). 
erate power, and to reduce floods. ${ }^{9}$ Mill dams had provided water for industrial processing as well as to turn water wheels, and in some instances, they stored water for municipal purposes, but they typically were single-purpose and small in height. ${ }^{10}$ With the coming of long-distance electricity transmission in $\mathrm{I} 89 \mathrm{I}$, electric power began to be linked with other purposes. Thus, in the United States, the Bureau of Reclamation combined electric power and irrigation storage at the Minidoka Dam on the Snake River in 1909 and at the Roosevelt Dam on the Salt River in Igrr. ${ }^{11}$ And the Hetch Hetchy water supply, with its controversial use of National Park lands to aid in furnishing municipal water and power for San Francisco, had commanded public attention from I9I3 until construction began in $1924^{12}$

Nowhere in South America, Asia, or Africa was there a major multiple-purpose storage project. This is not to say, of course, that there were no combinations of two or more purposes in water storage or that the concept of multiple use was not current in public thinking. The irrigation barrages constructed under British supervision in India as a measure of famine prevention in drought areas had provided for some use of water for domestic purposes, a use ever common where water is conducted through a dry area, and their irrigation canals had been used for navigation where suitable. Engineers, using the new knowledge of electricity, had sought to install power turbines where water fell through conduits to supply municipal needs. And a few river canalization schemes had installed generators in connection with navigation locks, thus capturing the energy otherwise lost. In eastern Asia, too, works on the lower stretches of streams combined navigation or flood control with irrigation.

A different form of multiple-purpose project, not involving storage, however, had already taken shape in the lower reaches of a few navigable streams, such as the Seine, the Po, and the Mississippi, where, by the construction of cutoffs, deepened channels, or training works, it was practicable both to improve the all-season navigability of channels and to hasten the flow of floods, thus reducing the area and depth of flooding. Likewise, the Dutch and English engineers, operating along their coasts and in the English Fens, had, as early as the seventeenth century, devised schemes which would dispose of flood waters and reclaim land for agriculture through subsidiary drainage. Strictly speaking, drainage goes hand in hand with flood control wherever the latter is practiced by channel regulation, and the Yazoo and the Chao Phya provide excellent examples of this.

In all these countries, the vision of multiple-purpose development was far ahead of the practice. By I890, Sir Wilfred Willcocks was dreaming of dual-purpose dams on the Nile-indeed, a system of them-and viewed his design for the low Aswan structure as the precursor for what might follow on a large scale. ${ }^{13}$ A German engi-

\footnotetext{
- See Intze, Entwickelung des Thalsperrenbaues in Rheintand und Westfalen von i889 BIs r903 (n.d.).

${ }^{10}$ See Leffel's Construction of Miri Dams and Bookwalter's Millwright and Mechanic (I88i).

21 Bureau of Reclamation projects are described in its Dams and Control Works, various editions.

${ }^{2}$ For a recent review of the controversy, see Hearings before the Committee on Public Lands of the House on H.R. 5964, 77th Cong., 2d Sess. (I94r) (amending the Raker Act).

${ }^{13}$ W. Whllcocks, The Nile Reservorr Dam at Aswan aNd After 13-26 (I90I).
} 
neer, Mattern, using the work of Intze and others, was pleading in rgoz for multiplepurpose projects as the key to more intensive water use. ${ }^{14}$ Similar thinking is also to be found in the report of the United States Inland Waterways Commission in Igo8, which, while deeply concerned with problems of public-private responsibilities for water transport and water power and with coordination of federal activities, recognized the possibilities of combining irrigation, navigation, power, flood control, water supply, and related purpose in the same programs. ${ }^{15}$ And writing in 1915, the Professor of Civil Engineering at Harvard was saying about water power: ${ }^{18}$

This power arises from the water flowing in a stream, but this stream affords other uses, as for irrigation, water supply, and navigation. For the proper conservation of the water in a stream, all these four uses must be considered. Its development for one purpose must, so far as possible, be consistent with its development for the others. All should be developed so as to be productive of the greatest total good. The four uses above referred to are inseparably connected; particularly so are the two uses of a river for water power and for purposes of navigation, in cases where both of these uses are economically practicable.

In view of the early articulate championing of multiple-purpose approaches, it may be asked why a project such as Hoover Dam did not materialize sooner. Part of the explanation rests upon the perfection of engineering techniques. Multiple-purpose storage design generally means larger structures, and these require refinements of foundation treatment and mass design in order to carry the larger load. Concrete was not adapted to dams of large height until the early I900's, and then it remained for Arrowrock Dam in 19I5, with a height of 354 feet, and, by way of culmination, Hoover Dam to perfect the means of pouring large blocks as much as sixty feet across. ${ }^{17}$ The method of rolling raw earth into great structures, such as at Ft. Peck on the Missouri, was not developed until later years, for while it is cheaper in materials, it depends for its economy upon large-scale earth-moving machinery and for exact knowledge of methods of handling soil foundation materials, which did not become available until the I920's. ${ }^{18}$ Until some of those new techniques were in use, the building of large earth dams, particularly on streams in semiarid or arid regions, was a hazardous occupation.

14 E. Mattern, Der Thalsperrenbau und die Deutsche Wasserwirtschaft 100 (1902).

${ }^{\text {It }}$ Inland Waterways Comm'n, Preliminary Report, S. Doc. No. 325, 6oth Cong., Ist Scss. 18-25 (I908). M. O. Leighton's "Relation of Water Conservation to Flood Prevention and Navigation in Ohio River" is an appendix, id. at $45 \mathrm{I}-90$, critically reviewing the opposition to the Ellet plan for reservoirs. Ellet's plan for a reservoir system on the Ohio was hailed by his publisher in 1853 as "the foundation of a new branch of engineering, which, in the progress of the country in wealth and population, is destined to acquire increasing interest from year to year." Charles Ellet, JR., The Mississippi and Omo Rivens vii $(1853)$.

${ }^{10}$ George F. Swain, Conservation of Water by Storage 24-25 (1915).

${ }^{17}$ U. S. Bureau of Reclamation, Dep'T of Interior, Dams and Control Works 7-10, 49-51 (1938). Willcocks, in his design of Aswan, saw it as marking a new "epoch in dam building," especially as the use of concrete might come to be perfected, but he thought of the typical combination of purposes as being flood control and irrigation. Willcocks, op. cit. supra note 13 , at 4 .

${ }^{28}$ The Miami Conservancy District pioneered with draglines for building hydraulic fill dams with clay cores. The pioneering worker on the physical properties of soils as applied to cngincering was Karl Terzaghi. Smaller earth dams had been constructed over at least 1,600 years in India and the Micldle East. 
Other factors than dam design and construction also were at work. Perhaps most important, improvement in methods of long-distance transmission of electricity was rapid between Ig0o and I925, so that a line of I00 miles, considered uneconomic by operating companies in I9ro, seemed short by comparison with the 200-mile line which the Southern California groups were prepared to build to Hoover Dam in 1929. Power clearly was the most readily vendible of all the products of multiplepurpose dams: municipal water supply might warrant heavy investment, but it was not as easily distributed and sold. Once cheap transmission became practicable, the active market for power for residential and industrial use grew at breath-taking speed. For many projects, the combination of vendible power made attractive an enterprise that otherwise would have commanded little attention if solely for irrigation or flood control. ${ }^{19}$ Electricity generation played a major role at Hoover Dam, in the pioneer French plans for the Rhône in 1933, and for the larger multiplepurpose structures in India, such as the Bahkra Dam on the upper Sutlej.

The private power companies in the United States, however, vigorously opposed the incorporation of power-generating facilities in public water-storage facilities. Threat to their monopolistic position under public franchise was one consideration in their opposition, which also stemmed from a deep concern with the constitutionality of direct government action in power generation. The moment that it was proposed to combine power generation with a purpose such as navigation, which was the exclusive function of the federal government, complications arose, because the private companies obviously could not be expected to take direct responsibility for navigation or flood control or noninterest-bearing reclamation projects. On their side, the advocates of public power opposed any grant of authority to private companies to develop power in single-purpose projects on streams under public control. The General Dam Act of Igo6 was the first broad legislative effort in the United States to deal with the conditions in which nonfederal development might take place on navigable waters and gave special attention to preventing interference with navigation and fish movement. ${ }^{20}$ There followed a long controversy culminating in the Federal Water Power Act of 1920 , with its much more precise regulation of nonfederal development. ${ }^{21}$ The issue was both federal and state, having been drawn, for example, in 1908 in New York, when the State Water Supply Commission proposed public construction of a dam on the Sacandaga River to reduce floods and produce electric power. ${ }^{22}$

Opposition also was supported by inertia in design and by the widely held view

\footnotetext{
${ }^{20}$ This view of electric power as the integrating factor in river basin development was widely preached by Morris L. Cooke. See Cooke, Multiple-purpose Rivers, 237 J. FrankLIN INST. 25I (1944). See also Lepawsky, Dams and Democracy, 29 VA. Q. REv. 533 (1953).

${ }_{20} 34$ STAT. 386.

21 4.I STAт. I063, as amended, 49 STAт. 838 (I935), I6 U.S.C. \$\$79ra-825r (1952). This history is described in Prestdent's Water Resources Policy Coman' op. cit. supra note 3, at 39r-408 (r950).

${ }^{22}$ State Water Supply Comm'N of New York, Studies of Water Storage for Flood Prevention and Power Development in New York State onder Public Ownership and Control I4-15, 18 (Ig08).
} 
that on grounds of design safety and economy, it often was impracticable to combine power with certain other purposes. Thus, an examination of a dozen civil engineering textbooks published during the first three decades of the century shows little or no attention to multiple-purpose design. And a special committee of the American Society of Civil Engineers, in its progress report on Mississippi River flood problems, in Igr6 stated: $:^{23}$

There is a popular delusion that the same reservoir can be utilized simultaneously to reduce floods, increase the low-water discharge of a stream, and increase the water-power that can be developed therefrom, but ordinarily its utilization for any one of these purposes precludes its efficient use for either of the others. . . Y Your committee, however, does not intend to condemn in toto the utilization of reservoirs for more than one purpose. In fact, it believes that the practical solution of the flood problem in some valleys will be found in permitting corporations to build reservoirs in which a portion of the stored water can be utilized to a limited extent for power purposes and the remainder for flood prevention....

One of the standard texts on water-power engineering was still taking a somewhat similar position ten years later. ${ }^{24}$ The single-purpose approach persisted. Perhaps the extreme public demonstration was in the case of the Miami Conservancy District, where, under a new Ohio state conservancy law following the tragic flood of I $9{ }_{3} 3{ }^{25}$ the District constructed a system of channel improvements and five detention reservoirs to prevent any repetition of peak floods. The reservoirs were designed to detain water only long enough to permit the outflow to be limited to bank-full capacity downstream. On each dam was placed a plaque reading as follows : $^{26}$

${ }^{23}$ Hearings before the Commitiee of the House on Flood Control on Mississippi River Floods, 64th Cong., rst Sess. 295-96 (rgI6). One of the members, Morris Knowles, dissented, calling this statement "an entirely unnecessary and unfair discussion purporting to show that reservoirs cannot be made uscful for flood prevention, together with other purposes; whereas we know, on the contrary, that, notwithstanding all these statements, it is possible to operate reservoirs with several purposes in vicw, and that is actually done in some of the great reservoir systems of Europe and America without conflict of interests." Id. at $30 \mathrm{I}$.

34 "Storage capacity below spillway level cannot be devoted to both power and storage unless at all times some portion at the upper level is reserved for flood use and kept empty, and, therefore, always ready for the flood emergency. In this country such joint use of reservoirs has not been attempted, their purpose always being water storage for power, municipal water supply, or navigation, so that any decrease of flood tendencies has been mercly incidental." H. K. Barrows, Water Power Engineering r8o (1927).

${ }^{25}$ Act of Feb. I7, 1914, Ohio Rev. Code Ann. c. 6roi (Page r954).

${ }^{20}$ Arthur E. Morgan, The Miami Conservanct District 473 (195I). In passing, it may be noted that one of the paradoxes in river basin development history is that the head of the Miami Conservancy District at that time was Arthur E. Morgan, who later became a member of the first board of the Tennessee Valley Authority and a proponent of a multiple-purpose reservoir system for the entire Mississippi; while a leader in the negotiations culminating in the dam on the lower Colorado was Herbert Hoover, then Secretary of Commerce, who later came to oppose expansion of federal power activities in favor of private management of these resources. Hoover never shifted his basic position on the desirability of linking private power with public management of other resources, but he did find himself, as late as 1955, trying to stem a tide of public power activity which had taken strong impetus from the apparent success of Hoover Dam. See I Comm'n on Organization of the Exzcutive Branch, Water RESOURCES AND POWER Ir9-22 (1955). 
The Dams

of the Miami Conservancy district are for

Flood Prevention Purposes

Their use for power development

or for storage

would be a menace to

the cities below

For twenty years after I908, there were recurring federal authorizations of waterresources studies, in which the surveying agency was directed or permitted to consider other uses in addition to the major purpose in view. Thus, the Bureau of Reclamation was authorized to investigate power and later municipal water supply, ${ }^{27}$ the Corps of Engineers was authorized to consider power in connection with navigation and then flood control, ${ }^{28}$ and the Federal Power Commission was to take those other uses into account in reviewing applications for power-site permits. ${ }^{29}$ These did not specify the kind of report which was expected, however, and the agencies regarded them more as permissive than directive. Accordingly, water-pollution control was neglected throughout those decades; and although attention was given to preservation of fish life at dams early in the period, as the size of projects increased and competition between federal agencies also increased, the interests of recreation, wildlife habitat preservation, and esthetic enjoyment of wilderness lost out, and the conservation groups had to fight hard to gain any serious consideration from the engineers. ${ }^{30}$

The period of emergency public works in the United States in 1933-39, however, gave accasion for broad application of the multiple-purpose project idea across the country. Aided by substantial grants and loans in the interest of relieving unemployment, a whole series of new dams combining two or more purposes was constructed. They were favored, in principal, by the reviewing agencies; they offered the most widely distributed direct benefits; and they lent themselves particularly to public agencies, the only ones which could qualify for the public subsidy. In addition to the Tennessee Valley Authority, the Bureau of Reclamation launched the Grand Coulee, Central Valley of California, and Colorado-Big Thompson projects; the Corps of Engineers launched the Bonneville, Fort Peck, and upper Ohio projects; and various state agencies, such as the Nebraska power and irrigation authorities and the Muskingum Conservancy District in Ohio, obtained federal help. The reports of the Mississippi Valley Committee and National Resources Board and their successors gave heavy attention to multiple-purpose storage. ${ }^{31}$

${ }^{37}$ Act of April 16, 1906, 34 STAT. II6-17, 43 U.S.C. $\$ 567$ (1952). This permission to make provision for water supply and power did not take the form of a directive until Act of Aug. 4, 1939, 53 STAT. II94, 43 U.S.C. $\$ \$ 485$ (I952).

${ }^{88}$ Act of March 3, I909, 35 STat. 822, 33 U.S.C. $\$ 604$ (I952); Act of March I, I9I7, 39 STAT. 950, 33 U.S.C. $₫ 701$ (1952).

${ }^{30}$ Act of June Io, 1920, 4 I STAT. 1068, 16 U.S.C. §801 (1952).

${ }^{30}$ Specific instructions to consider wildlife were contained in Act of Dec. 22, x944, 58 STAT. 887, and Act of Aug. I4, 1946, 60 STAT. ro80, I6 U.S.C. $\$ \$ 66$ I-66c (1952).

${ }^{31}$ Mississippi Valley Commtttee of P.W.A., Report 25-29 (1934); National Resources Board, REPORT 27I-75, 286 (I934). 
By 1939 , multiple-purpose projects were the order of the day: the idea was accepted and considered practical, and, with the lag in private construction owing to depression conditions, the single-purpose storage project was no longer dominant.

Single-purpose projects were not abandoned, however; they only gave way to multiple-purpose projects in relative weight. Irrigation storage on the upper Rio Grande, flood-control dams on the Yazoo and Muskingum, navigation dams on the upper Mississippi, power dams on the Wisconsin were examples of structures that were considered best suited to serving a single aim. They have continued in relatively diminishing number, often a source of controversy that probably has had fullest recent public expression in the dispute over the development of privately-financed power dams in Hell's Canyon, on the Snake. In 1953, the chief of project planning for the Bureau of Reclamation could say: $:^{32}$

... multiple-purpose projects are now thoroughly accepted, and an engineer would be considered remiss if he did not consider all possible uses, in connection with the planning of any irrigation project.

\section{B. The Basin-wide Program}

While the idea of multiple-purpose storage was gathering force, there was a complimentary, but not corollary, formation of the idea of basin-wide development. Again, Willcocks, Powell, and others had seen that if regulation of stream flow was to be achieved fully, it could only be by harnessing the flow of an entire drainage basin, and this meant designing control works with a regard to all other worksexisting or possible-in the basin. Willcocks had made tentative plans for dealing with the Nile and Tigris-Euphrates basins as unified systems and was aware of, but not discouraged by, the political complications in store. ${ }^{33}$ Powell, observing from his studies of the arid and semiarid regions that each stream presented problems peculiar to itself, proceeded to appraise the irrigation possibilities of each basin separately. ${ }^{34}$ And President Theodore Roosevelt, in transmitting the Inland Waterways Commission preliminary report, could say: $:^{35}$

Each river system from its headwaters in the forest to its mouth on the coast, is a unit and should be treated as such.

The first major basin in the United States in which this idea was incorporated in a complete design was the Miami basin. There, as already noted, the program was strictly a single-purpose, flood-control effort. New York City, also, had undertaken to deal with entire tributary drainages of the Hudson River in single-purpose development of new water supply at the turn of the century, and while there had been no thought of covering larger areas, the concept of planning for the complete subbasin

${ }^{83}$ John Dixon, Planning an Irrigation Project Today, in Centennial Trans. Aar. Soc'y Civiz Eno. 357,362 (1953).

${ }^{38}$ Willcocks, op. cit. supta note I3, at 13-26; W. Willcocks, Irrigation of Mesopotamia (2d ed. I9I7).

8. J. W. Poweil, Report on the Lands of the Arid Region i0-14 (1879).

${ }^{20}$ Inland Waterways Comm'n, supra note 15 , at iv. 
had been established. ${ }^{30}$ Prior to that time, relatively complete development of small streams for mechanical water power had taken place, but not in accord with a single plan. $^{37}$

The same situation had prevailed in a more acute form along the alluvial valley of the Mississippi, where the multiplication of levee districts and drainage districts without clear relation to a basin-wide program had resulted in direct conflict and oftentimes serious injury among the various works, leading to increased federal participation. $^{38}$ It is significant that A. E. Morgan and his associates came directly out of efforts to plan drainage projects in the alluvial valley and had seen the folly of attempting to deal with large flood flows by taking small bites. The Miami, they were determined, was to be handled as a unit.

In the same year that major works were undertaken in the Miami basin, a $\mathrm{Na}$ tional Waterways Commission was authorized to prepare a comprehensive plan for the development of the nation's water resources for navigation and every useful purpose and to make recommendations for carrying out such work. ${ }^{39}$ War conditions deferred its appointment, however, and it never came to grips with the problems.

In France, the desirability of treating basins as units was recognized in law in I9r9, ${ }^{40}$ and in Germany and Italy, the concept was accepted by engineers as necessary to effective planning.

But even after the Miami program had been demonstrated, it was a long time before the idea caught on elsewhere in the United States. Clearly, it played a major role in the discussions leading to final authorization of Hoover Dam: the I922 compact recognized that the waters of the entire Colorado basin would need to be allocated under one agreement and that such allocation might lay the basis for designing works to control and use those waters. It was not sufficiently strong, however, to require that the final design of the first dam should be shown as a part of a system for the full basin. Nevertheless, the idea was finding progressively wider support in engineering circles, and threatening water shortages in western streams lent weight to it.

The great Mississippi flood of 1927 brought this thinking to focus. That catastrophe dramatized the inadequacy of Corps of Engineers' plans, which had sought to control flooding and maintain navigation channels along the main stem without planning works for the tributaries. Only the year before, the Chief of Engineers had reported that all was well with the levee and channel works. ${ }^{41}$ A national debate ensued on

so See Board of Water Sưpply of the City of New York, Catskitr Water Supply (ig28).

${ }^{97}$ Mill owners did, however, maintain organizations to deal with their interests in an entire stream, and engineers saw the possibilities of large-scale unified development. See, e.g., JosepH FrizeLr, WATERPOWER 588-605 (1903).

${ }^{38}$ See Robert W. Harrison, Levee Districts and Levee Building in Mississtppi: A Study of Stati and Local EFforts to Control Mississippi River Floods (195I).

${ }^{30}$ Act of Aug. 8, r917, 40 Stat. 250 (repealed in 1920).

${ }^{\circ} \mathrm{Law}$ of Oct. 16, 1919. See Arbelot and Dupin, L'evolution des idées en matiere de regularisation de l'energie hydroelectrique, in 2 Trans. First Wordd Power Conference 150-54 (I924).

¿2 U. S. WAR Dep'T, RePoRT of THE ChIEF of ENGINEERS, U. S. ARMT, I926, pt. I, at I793, 1794 (x928). 
the efficacy of levees versus cutoffs versus dams versus forests. Many extreme and poorly grounded assertions were made, and out of the heat and confusion, there emerged a few policy agreements. In the River and Harbor Act of 1927 , Congress authorized comprehensive examinations and surveys by the Corps of Engineers to formulate ${ }^{42}$

... general plans for the most effective improvement of [navigable streams and their tributaries] for the purposes of navigation and the prosecution of such improvement in combination with the most efficient development of the potential water power, the control of floods, and the needs of irrigation.

This was the second time in American history that a public agency had been directed to make comprehensive studies of navigation, flood control, irrigation, and power for complete drainage basins, but the first to have effect. The "308 reports," as they were known from their areas having been described in House Document No. $308,{ }^{43}$ became the point of departure for river basin development in the United States. Under the authority of the 1927 act, the possibility of multiple-purpose projects for at least four major purposes was recognized, and the comprehension of all parts of the basin in a single report was required. In doing so, it brought together federal concerns that had grown up along four separate lines of navigation, flood control, irrigation, and power policy.

Of the many basin programs that emerged in later years out of 308 reports-the Columbia, the Missouri, the upper Ohio-none commanded more attention than the Tennessee. After the 1927 authorization, the Corps of Engineers decided to concentrate its studies in the early years on one pilot basin. They selected the Tennessee, in part because it seemed to lend itself to unified planning, in part because it was endowed with a relatively generous amount of basic hydrologic data, and in part because the Government was confronted with the difficult decision of what to do with Wilson Dam, a hydroelectric plan at Muscle Shoals which had been constructed during World War I to provide power for manufacture of nitrogen. It was the Corps of Engineers which prepared the first plan for the Tennessee, and when the Tennessee Valley Authority Act was passed by Congress in $1933,{ }^{44}$ the Corps plan was the available one. ${ }^{45}$ The new Authority set up its own engineering staff and asked the Bureau of Reclamation to aid in revising the plans so as to design a series of high dams having large hydroelectric output, rather than the moderately low dams designed by the Corps to serve navigation primarily and to produce relatively small

${ }^{22} 44$ Stat. 1015. The list was prepared by the Federal Power Commission and Corps of Engincers, in accordance with Act of March 3, 1925, \$3, 43 STAT. 1190.

${ }^{13}$ H. R. Doc. No. 308, 69th Cong., 1st Sess. (1927).

${ }^{4} 48$ STat. 58 (1933), I6 U.S.C. $\$ 831$ (1952).

${ }^{45}$ H. R. Doc. No. 328, 71st Cong., 2d Sess. (1930). It is doubtful whether or not Congress was aware of the possible implications of the Corps of Engineers' low-dam plan for later high-dam construction at the time that the act was passed. It might have been thought that only one or two new structures (Cove Creek and Wheeler locks) would be built. Later legislation was required to define clearly the authority for river basin planning. See C. Hersan Pritchett, The Tennessee Valley Authority, A Study in Pubic Administration 3-47 (1943). 
amounts of power. Thus, the Tennessee basin was the first to be studied with a view to designing a single, unified program, and it was the first in which such a program was authorized for construction. As the TVA worked out its revised designs over the years, it developed a program under which there are twenty-seven dams serving navigation, flood control, and hydroelectric power, operated so as to regulate flow throughout the main stem and major tributaries and to contribute to reduction of flood flows in the lower Mississippi. From the standpoint of historical evolution and of popular regard, the TVA may be considered the prototype for unified basinwide programs of multiple-purpose projects. It was intended to demonstrate the feasibility of such programs, and it clearly has done so.

Throughout the late I930's, the National Resources Committee and its successors promoted thinking among both federal and state groups on the meaning of drainage basin plans by drawing them together to assess needs and to attempt to agree upon unified programs of investigation and construction. ${ }^{46}$ Several significant basin-wide programs already were on the drafting boards about the time that the TVA took shape. One of these was the Rhône plan, which had its inception in the device of French engineers to combine further navigation improvements with power generation. ${ }^{47}$ In Spain, a national survey of water resources had recommended unequivocally in 1933 for the treatment of rivers as units. ${ }^{48}$ The Central Valley plan in California had been proposed as early as I 921 and was authorized by the state in 1933, but awaited federal financing. ${ }^{49}$

There is little doubt that all the integrated systems of multiple-purpose projects attempted since the r930's were influenced in some degree by the TVA, Columbia River and Central Valley works. Probably more important than the direct connections, of which there are many, has been the fact of accomplishment, the patent demonstration that what engineers around the world had been describing as possible and feasible could be built and operated in a relatively short time. ${ }^{50}$

\section{Comprehensive Regional Development}

The third of the major ideas in unified river development is more difficult to describe than the other two, because it has not been fully realized in any part of the earth. There is no prototype, no sterling demonstration of the idea; only partial, incomplete ventures in a direction that is, thus far, obscure. Implicit in the Hoover Dam project and in the TVA was an aim that, while assumed in much federal resources activity for more than a century, was not explicitly stated in the legislation and has not been fully realized. It was the aim of so planning and carrying out the

\footnotetext{
${ }^{10}$ Sce Natjonal Resources Committee, Drainage Basin Problems and Programs (1936). See also revision of committee reports in 1937.

${ }^{17}$ See Gilbert Tournier, Rhóne: Dieu Conquis (1952). Planning had been authorized by an act of May 27, 1921, and an administrative order of Jan. $13,193 \mathrm{r}$.

" Plan nacional de obras hidráulicas (I933).

'See Hugh G. Hansen, Centrai Valiey Project: Federal or State? 2i-37 (Cal. Assembly Interim Comm. Rep., Vol. 13, No. 6, 1955).

${ }^{\circ}$ Sec TVA, TVA as a Symbol of Resource Develupment in Many Countries (I955).
} 
works for river regulation and use that the region in which the basin is located would enjoy maximum practicable stimulation of its economic and social growth. ${ }^{51}$

The roots for such concern seem to go deep in United States public works and public land development. Gallatin's plan for waterway improvement, Powell's program for treatment of the arid lands, and Newland's early pleas for federal subsidy to western irrigation had presumed wise use of public material resources or capital to stimulate economic growth.

To take our two examples, the Hoover Dam was recognized by its proponents and opponents as likely to promote economic growth in the lower Colorado basin and in Southern California as well, although it was not specifically designed to effect such growth in a particular way. The Tennessee Valley projects were believed to be beneficial in sparking growth of what had been regarded as a backward and depressed region, but beyond this hope and the direction, given at the last hours in framing the act- ${ }^{52}$

Sec. 22 To aid further the proper use, conservation, and development of the natural resources of the Tennessee River drainage basin and of such adjoining territory as may be related to or materially affected by the development consequent to the Act, and to provide for the general welfare of the citizens of said areas, the President is authorized, by such means or methods as he may deem proper within the limits of appropriations made therefor by Congress, to make such surveys of and general plans for said Tennessee basin and adjoining territory as may be useful to the Congress and to the several States in guiding and controlling the extent, sequence, and nature of development that may be equitably and economically advanced through the expenditure of public funds, or through the guidance or control of public authority, all for the general purpose of fostering an orderly and proper physical, economic, and social development of said areas . . . -

the Authority was not explicitly designed to occupy itself with those questions. Research on the impact of navigation upon industrial life, or on the relation of retail power rates to domestic electricity consumption, or on the efficiency of various cropping and fertilizing methods was undertaken to supplement and make more effective the water resources and fertilizer projects, rather than as a basis for deciding what form of project should be undertaken, where, and when. Repeatedly, the officers of the TVA, from its earliest years, noted with satisfaction the effects of their activities upon the economy of the area loosely described as the "TVA Region" or the "southeastern region." This was summed up most recently by Gordon Clapp, who pointed to increase in nonagricultural employment, increase in variety of economic opportunities, rapid growth of high-wage industries, a new pattern of industries process-

\footnotetext{
${ }^{51}$ The term "region" is used here in its broadest sense to include any area designated for study or action. For discussions of more precise uses, see National Resources Committee, Regional Factons in National Planning and Development (1935); and Platt, Discussion: Nature and Scope of Regional Science, in 2 Papers and Proc. Regronal Science Ass'n 46 (1956).

5248 STAT. 69 (1933), I6 U.S.C. \$83Iu (1952). The broad, regional studies were not undertaken at once, but they followed soon, and the legislative authority was sufficiently general to permit their being undertaken. Ackerman, Tennessee Valley Authority Planning: Methods and Results, in PAPERs op INT't Conference on Regional Planning and Development (1955), gives a careful review of the development of those activities.
} 
ing raw materials, electrification of farms, and rural self-improvement projects as indices of growth stimulated by the Authority. ${ }^{53}$ The stimulation of local citizen participation in valley improvement is counted both as essential to and an important outcome of unified regional development activities.

In both the Hoover Dam and TVA examples, regional effects were intimated but not planned, then enjoyed but not managed. They were dimly perceived at the start, hailed when apparent, and the subject of earnest study after the crucial decisions as to major river regulation works had been made. In each case, the criteria for selection and financing of the construction work were restricted to a showing of teasibility for the stated purposes of water control. Such gauges of economic wellbeing as per capita income, diversification of industry and agriculture, and stability of employment did not figure in decisive ways. These entered the discussion of the wisdom of the projects more as rationalizations than as prior justifications.

A similar chronology occurred with the construction of Grand Coulee Dam on the Columbia River in Washington by the Bureau of Reclamation. Grand Coulee was part of a basin-wide scheme in the sense that it had been selected by the Bureau of Reclamation as a major element in a program for water development in the Columbia; but it was not a part, strictly speaking, because it was authorized long before substantial agreement had been reached among the Bureau of Reclamation, the Corps of Engineers, the Fish and Wildlife Service, and the various state interests as to the full outline of such a program. ${ }^{54}$ Once underway, however, its full effects became a subject of lively speculation, leading the Bureau of Reclamation, with the leadership of Harlan Barrows, to initiate the "Columbia basin joint investigations." The scope of those studies is suggested by the participants, including nineteen federal agencies, eleven state agencies, and thirteen local and private institutions, and by the twenty-eight problems set for investigation. ${ }^{55}$ Those problems covered questions of farm economy, farm size and layout, control of land use, village and community centers, transport facilities, recreational needs, and public works programming and financing.

Expected answers to such questions have figured repeatedly in the justifications given before public groups for Grand Coulee and also in descriptions given of results expected from many other basin programs modeled, in part, upon the TVA experience. Thus, the arguments made in favor of the Damodar Valley Authority in India have carried statements that $:^{56}$

The Corporation is to execute and operate schemes for irrigation, the generation of power and flood control. Besides those three main purposes, the Corporation will promote navigation, afforestation, public health, and industrial, economic and the general well-being of the people of the Valley.

${ }^{23}$ Gordon R. Clapp, The TVA: An Approach to the Development of a Regron 54-56, 65 (1955).

54 See Charles McKinley, Uncle Sam in the Pacific Northwest I38-45 (1952).

Ez U. S. Bureau of Reclamation, Dep't of Intertor, Colvmbia Bastn Joint Investigations: CharACTER AND SCOPE (I94I).

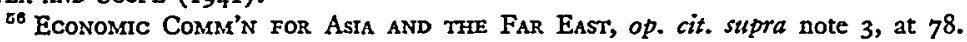


The distinction which seems crucial here is between engineering works which are planned and carried out with the sole purpose of gaining the direct benefits, such as power production or flood damage reduction from the water regulation, and engineering works which are intended to promote basic changes in the quality of life of the residents of the region. Under the second view, two considerations enter which are ignored under the first. The direct benefits become a means to an end, rather than an end in themselves; and engineering becomes one of several possible instruments, including land use, which may serve the needs of regional change. In the Miami Conservancy District plan, there was earnest desire to prevent future flood losses and to stabilize the then prevailing economy, but no concern to effect any significant changes in the distribution or character of urban occupancy in the basin: the aims stopped with the achievement of flood control. As the TVA unfolded, however, the control of floods was seen as a method of advancing a new economic and social wellbeing of residents of the Tennessee Valley, and power and navigation were viewed similarly. The moment in an analysis of a river basin development opportunity that this first distinction is made and that the construction of physical works takes on larger implications, the second distinction arises. If engineering is a means toward an end, then other means deserve attention as possibly contributing to or alternately serving the same end. ${ }^{57}$

Under the broadened view, the Bureau of Reclamation becomes as much concerned with the maintenance of family-sized farms as with optimum dimensions for distribution canals; and the Tennessee Valley Authority, from the beginning of its power program, lays stress on the marketing practices of farmers' electricity cooperatives as well as on the integration of hydroelectric and thermal-electric generating stations in the maximization of firm power production. Land use improvement, the economics of potential mineral exploitation, and the relation of freight rates to traffic movement and manufacturing location, are among the lines of inquiry that vie in importance with standard hydrologic and civil engineering practices in the planning of the river basin development.

It may appear that to take this broader view of river basin development is to expand water resources planning to encompass all aspects of natural resources as related to economic growth, including the cultural conditions of the society, and it will be necessary to ask whether or not there is any viable line which may be drawn between one and the other. For if there is no viable line, the attempts to carry water resources analysis beyond the traditional concepts of multiple-purpose, basinwide development must inevitably lead to comprehensive regional development schemes in which water, in many instances, would play a secondary role.

Without attempting to answer that question, it may be useful to observe that no clear pattern of associated regional activities has yet emerged from the experimentation that currently is in progress in river basin development. It is not even possible

\footnotetext{
${ }^{57}$ A succinct statement of the idea of comprehensive regional development, as it took shape in the 1930's and 1940's, is Alvin H. Hansen \& Harvey S. Perloff, Regional Resource Development (1942).
} 
to find association of electricity distribution and electricity production activities where hydroelectric plants are in operation. For example, the Compagnie National du Rhône avoids any connection with marketing policies for the power which it sells in bloc to Electricité de France. ${ }^{58}$ In general, the basins having more nearly unified administrative control of their water-regulation works have a larger number of associated activities directed at steering regional growth.

There is little clarity as to whether the aim of such growth should be specialization or balance, and the indices of results are scattered and rudimentary at best. Measures of aggregate economic growth are handicapped by lack of data, as well as by incompleteness of the theory of the process of growth. Less tangible noneconomic growth is even more difficult to quantify. There have been earnest efforts to improve the measurement devices, but these are still far from keeping pace with the claims of project proponents..$^{59}$ The claims for "secondary benefits" from investment in irrigation facilities continue to be in controversy among federal agencies. ${ }^{60}$

In its lack of definition and in difficulty of gauging the results of its use, the idea of comprehensive regional development has less precision and form than either multiple-purpose storage or basin-wide plan.

\section{III}

\section{Associated Ideas}

In addition to the three ideas described above, two others have enjoyed some popularity and individually have found expression in one or more development programs. They are less widely applied than the three already described and less firmly grounded in either theory or demonstrated practice, although they have attracted, in some instances, greater attention. One is the concept of articulated land and water programs; the second, the concept of unified administration. The former has commanded adherence over long periods and receives lip service generally today, but is honored r 933 and has been kept alive by controversy and opposition rather than by acceptance. more in theory than in practice. The latter bloomed suddenly and vigorously after

\section{A. Land and Water}

Early in the histories of scientific agriculture and river engineering, the idea took shape that the management of land and its vegetative cover is closely linked with the proper management of the flow of water in streams, that the magnitude, variation, and quality of water moving in a drainage basin is, in some measure, influenced by

${ }^{48}$ See Tournier, op. cit. stipra note 47 , at 304-05.

${ }^{\text {6n }}$ Problems of economic indices are outlined in Krutilla, Criteria for Evaluating Regional Development Programs, 45 AM. Econ. Rev. 120 (1955). Moore, Regional Economic Reaction Paths, id. at 133; and the discussion that follows. Id. at $\mathrm{r} 49$.

${ }^{\circ}$ Federal Inter-agency River Basin Committee, Proposed Practices for Economic Analysis of River Basin Projects (1950). See also Techical Assistance Administration, Formulation and Economic Appraisal of Development Projects (U.N. Pub. Sales No. I95I.II.B.4.); and U. S. Bureau of Reclansation, Dep't of Interior, Report of Panel of Consultants on Secondary or Indirect Benefits of Water-Use Projects (I952). 
the treatment of the land. Although the origins of this idea are not clear, ${ }^{01}$ it does seem to have been widely held in western Europe by the beginning of the nineteenth century. Summing up much of the study in the middle decades, Marsh found a weight of evidence that forests affect the rise and fall of springs and normal volume of rivers and the character of floods in rivers and torrents. ${ }^{62}$ French engineers and foresters long had been concerned with relationships between their two lines of action, principal attention being given to the restoration of denuded sections of the High Alps. Agitation for regulation of forest and grazing practices as a means to controlling mountain torrents were suggested by administrative officers in $18 \mathrm{rg}$, and the first timid national legislation was passed in 1859 , with major legislation following in $1882 .{ }^{63}$

Action was much slower in the United States, where problems of denudation were then considered less acute. For example, Gilbert, on the basis of reconnaissance studies in Utah, was not concerned with threats of accelerated erosion and concluded that if man did have an effect upon stream flow in the Rocky Mountain region, it probably would be advantageous by increasing the supply. ${ }^{64}$ In the I89o's, however, some of the foresters began agitation for federal acquisition of forested lands in the drainage areas of important streams and for the retention of federal control over such lands where they had not passed to private ownership. ${ }^{65}$ This culminated in the Weeks Law of IgII, which established federal acquisition of such forested, cutover, or denuded lands as "may be necessary to the regulation of the flow of navigable streams." The forest program was expanded in 1924 to deal more explicitly with production problems, and there was a flurry of interest in forests as a preventive for floods following the 1927 disaster.

Then, three events placed agricultural workers directly in the river basin development field. The establishment of the Soil Conservation Service, ${ }^{07}$ under Hugh Bennett, led to vigorous studies of channel and reservoir silting, to the establishment of experimental watersheds, and to the study of erosion conditions and corrective measures on a drainage basis. In 1936, the Flood Control Act, which shouldered federal responsibility for flood damage reduction on a national basis, authorized the Secretary of Agriculture to make surveys of "measures for runoff and water flow retardation and soil erosion prevention." ${ }^{\text {"8 }}$ The TVA Act also permitted the establish-

${ }^{61}$ No attempt is here made to trace the earlier evolution of this idea. It occurs in much Greck, Hebrew, and Roman literature. For a brief review of evolving views of the unity of nature, see Glacken, The Origins of the Conservation Philosophy, ir J. Soll \& Water Conservation 63 (1956).

${ }^{62}$ George Perkins Marsh, The Earth as Modified by Human Action 225, 227 (1885). Marsh did not feel warranted in asserting, however, that forests, by their presence or absence, increase or lessen the total volume of water discharged by rivers or torrents.

${ }^{3}$ See M. P. Mougin, La restauration des Alpes 145-6o (r93I).

${ }^{a}$ Gilbert, Water Supply, in Powell, op. cit. supra note 34, at 57. Interest then centered on prospects for climatic fluctuations.

${ }^{85}$ See Gifford Pinchor, Breaking New Ground 238-40 (x947).

${ }^{60}$ Act of March I, rgII, 36 Stat. 96r, as amended, r6 U.S.C. \$\$515-16 (r952). (1952).

${ }^{\text {ez }}$ Act of June 16, I933, 48 Stat. 195, and Act of April 27, 1935, 49 STAt. 163, I6 U.S.C. \$590

${ }^{8} 49$ STAT. I570 (1936), 33 U.S.C. $\$ 701(a)$ (1952). This was extended by Act of Aug. 28, r937, to cover all drainage areas previously authorized for survey by the Corps. 50 STAT. 877,33 U.S.C. $\$ 701$ (g) (1952). 
ment of divisions of forestry and agricultural relations. Out of these surveys by agricultural experts, there came a series of reports recommending appropriate measures for land-use treatment in selected drainage areas. These were the subject of extensive and often controversial review by the Corps of Engineers and Bureau of Reclamation. Eleven of the basin plans were completed, others delayed, and, with interruptions caused by war conditions and by problems of administrative jurisdiction within the Department, the program slowed down until the Department of Agriculture's interest in river programs was sharply revived by enactment, in 1954, of a new watershed-protection and flood-prevention program, under which direct action could be taken more readily by departmental agencies in cooperation with the land owners. ${ }^{69}$

A notable feature of the evolution of action by the land-management agencies is that, with a few exceptions, the work recommended on the land was not of such a character or degree of reliability in its effects upon water flow as to warrant making any changes in engineering works proposed for the same drainage areas. That is, flood-control reservoirs were not rendered needless by the prospect of stopping flow upstream, and storage reservoirs were not obviated by retention of water through forest or cropping practices. Such a conclusion was strongly at variance with the beliefs of many advocates of land management as an alternative to engineering and provoked a series of running debates which, in later years, centered successively upon the work of the President's Water Flow Committee, the Trinity River study, and the cooperative investigation of the Washita Basin. ${ }^{\text {70 }}$

While this is not the place to enter into the jousting over land management versus engineering in river basin development, it may be useful to offer a few observations on the problem by way of partial explanation for some of the difficulties. The idea that land management may have an important effect upon water flow has received wide publicity in the United States in a series of reports over half a century. ${ }^{71}$ It has not been translated into action in more than a few instances, because the responsible engineers have been either unable or unwilling to recognize direct and reliable connections with their programs. ${ }^{72}$ One difficulty has been that proponents

${ }^{00}$ Act of Aug. 4, I954, 68 STAT. 666, I6 U.S.C.A. $\$ \$ 1001-06 \mathrm{~b}$ (Supp. 1956).

${ }^{70}$ See President's Committee on Water Flow, Report, H. R. Doc. No. 395, 73 d Cong., 2 d Sess. (I934).

${ }^{71}$ Some of the notable statements are: W. W. Ashe, Special Relations of Forests to Rivers in the United States, S. Doc. No. 325, 6oth Cong., Ist Sess. 514-34 (x908); U. S. Dep't of Agriculture, $A$ National Plan for American Forestry, S. Doc. No. I2, 73d Cong., Ist Sess. 299-46I, I509-36 (I933). Upstream Engineering Conference, Headwaters Control and Use: A Summary of Fundamental Principles and Their Application in the Conservation and Utilization of Waters and Solls Throvghout Headwater Areas (r937).

72 Thus, the ASCE Special Committee reported in 1916 : "The effects of forest growth in preventing erosion on hillsides are sufficient to justify reforestation for that purpose, but there has been no quantitative determination of its influence on stream flow which would justify its employment as a method of flood prevention." Hearings, supra note 23, at 298.

An example of the contrary view is: "The forest tends to equalize the flow throughout the year by making the low stages higher and the high stages lower.

"Floods which are produced by exceptional meteorological conditions cannot be prevented by forests, but without their mitigating influence the floods are more severe and destructive." Raphael Zon, "Forests and Waters in the Light of Scientific Investigation," in National Waterways Comm'n, Final Report, S. Doc. No. $469,62 \mathrm{~d}$ Cong., 2d Sess. app. V, at 205, 273 (r9r2).

A more reconciling view is this: "Forest rehabilitation is not urged as an alternative to engineering 
of each view have tended to exaggerate their own claims and to minimize those of others, so that foresters have at times claimed that reforestation would reduce the greatest Ohio floods, and engineers have maintained that soil erosion control had no part whatsoever in the sediment movement of streams.

The lack of scientific knowledge on which to settle disputes of that character has prevented clear answers and has permitted the controversies to continue inconclusively. Much information still is lacking. For example, the mechanism by which sediment finds its way into small watercourses is understood imperfectly, and the effect of land management upon ground-water flow is uncertain in many areas. It is only in recent years that it has been practicable for scientists to suggest valid generalizations as to the relationship between timber cutting and water yield or as to the possible effects of terracing upon flood flows. ${ }^{73}$

Thoroughly articulated programs of land and water development in the same basin, then, must be regarded as more hope than reality. They often have been joined in statements, but rarely in action.

\section{B. Unified Administration}

Following the enactment of the TVA Act, proposals for the creation of similar government agencies followed thick and fast for other basins. The distinguishing and common idea was the creation of an administration having full authority for dealing with whatever were the water and associated resource problems in the basin involved. Prior to that time, water projects characteristically were handled by the agency responsible for the major purpose. This might be a conservancy district for a flood-control problem, a city engineer department for a municipal water supply, an irrigation district and the Bureau of Reclamation for irrigation, a city or a drainage district and the Corps of Engineers for flood control. The Ruhr probably had the most complex administrative organization for its control works, involving several cities, two regional groups, and three drainage-area agencies. Now, the thinking turned to a single agency.

In the United States, proposals ranged from a general plan for subdividing the United States into valley authorities ${ }^{74}$ to individual agencies for the Columbia, the Missouri, and the Arkansas. None received congressional approval, although it may be argued that some had large nuisance value in forcing livelier activity and cooperation among federal agencies where the independent agency threatened. ${ }^{75}$ Indeed, the

works for flood control. It is supplementary to the engineering program, but it is a supplement of such importance that no complete plan of flood control can omit it." Sherman, "Protection Forests of the Mississippi River Watershed and Their Part in Flood Prevention," in U. S. Dep't of Agriculture, Relation of Forestry to the Control of Floods in the Mississippi River, H.R. Doc. No. 573, 7oth Cong., 2d Sess. 5t (1929).

${ }^{73}$ See Wilm, Timber Cutting and Water Yields, in Yearbook of Agriculture 593 (1949); LunA Leopold and Thomas Maddock, The Flood Control Controversy (I955).

${ }^{75}$ See McKinley, The Valley Authority and Its Alternatives, 44 AM. PoL. Scr. Rev. 607 (I950).

${ }^{75}$ It also may be argued that the results of these forced unions were more legitimate than in the public interest. See Hart, Governing the Missouri, 4I Iowa L. Rev. I98 (1956). 
number of federal and state agencies involved in water resource development has tended to increase. ${ }^{76}$

Outside of the United States, the pattern of unified administration has been adopted sparsely. The Compagnie National du Rhône enjoys much the same quality of independence of regular government agencies, functioning as a joint stock company. ${ }^{\mathbf{7 7}}$ In the United Kingdom, a system of catchment basin authorities was established in r930 to unify efforts to deal with land drainage, pollution abatement, flood control, and associated problems. ${ }^{78}$ These have been established in forty-six areas and function independently of the Central Electricity Board. When the North of Scotland Hydro-electric Board was set up in 1943 , however, its functions were limited to power production. ${ }^{79}$

Other agencies having unified control over the waters of entire basins include the Carini Valley Authority in Venezuela, the Caucas Valley Corporation in Colombia, the Damodar Valley Authority in India, the Snowy Mountains Hydroelectric Authority in Australia, and the Helman Valley Authority in Afghanistan. Each has variations from the TVA pattern. From the information available, however, all include an agency with powers to design, construct, and operate water-control works and to conduct associated activities, although they differ considerably in other respects. There has been no careful review of their functioning to date. It would appear that the idea of unified administration has spread from the Ruhrverband, TVA, and the English catchment basin experience to a few other areas, but is not, thus far, closely linked with large-scale river basin development.

\section{IV}

\section{Internattonal and Interstate Applications of the ConCEPT}

Efforts to deal with basins and regions as units have raised major problems of scale and of political organization. These are suggested in part by the location of basins with respect to political boundaries. Complexities of administrative jurisdiction clearly have played a role in the retardation of some river basin development programs but also have contributed to decisive action in others.

It will be observed from Figure I that a large proportion of the major drainage basins of West Europe, Africa, Southeast Asia, and South America are international in character. In the United States, the Soviet Union, and China, the opposite is true, although each has one or more major streams having international drainage. If basin-wide plans be taken as ultimately desirable, then it is clear that the Columbia, Colorado, St. Lawrence, Rio Grande, Orinoco, Amazon, Parana, Uraguay, Rhine, (1950).

${ }^{73}$ See White, National Executive Organization for Water Resources, 44 AM. PoL. ScI. Rev. 593

77 See Gilbert Tournier, L'amenagement du Rhône (r953).

${ }^{78}$ Under the Land Drainage Act of 1930,20 \& 21 GEo. 5, c. 44, catchment boards were established in England and Wales. They are composed of representatives of central and local government agencies concerned.

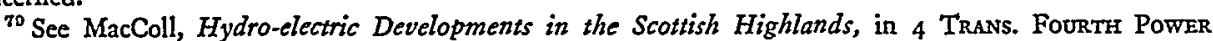
CONFERENCE 2158 (1950). 
Rhône, Danube, Tagus, Nile, Tigris-Euphrates, Congo, Niger, Zambesi, Indus, Ganges-Brahmaputra, Mekong, and Amur require international collaboration for their wise planning. Lesser streams could be mentioned, but this suggests the magnitude of the problem. Only the Mississippi, Don, Dneiper, Volga, Ob, Yenisey, Lena, Yangste, and Yellow, among the great rivers, are free from the complication of crossing man-made borders. ${ }^{80}$

Within individual countries, the difficulties do not stop. The complexity of political administration imposed by state boundaries is apparent in the United States where, as shown in Figure 2, more than three-quarters of the land area is drained by streams crossing one or more state boundaries. The proportion would be even larger if the streams draining into the Great Lakes were counted as interstate, since, strictly speaking, all of them drain into interstate lake waters and through the St. Lawrence River. They are treated on the map as intrastate units, however, although one major diversion is made down the Illinois River and although the Great Lakes states have, during 1956 , organized to begin the planning of work, such as port development, on an interstate basis. The major basins which are intrastate are the Central Valley of California, the Brazos, Colorado, and Trinity in Texas, and the Altamaha, Cape Fear, and James along the eastern seaboard.

Forty per cent of the area of the United States is drained by the Mississippi, a stream so great and complex that its planning has been largely in terms of subbasins. Even when subdivided, the interstate basins loom large, leaving only a few major streams such as the Wisconsin, Kaskaskia, Green, Miami, Scioto, Muskingum, and Yazoo lying wholly within one state. The picture for the western tributaries of the Mississippi is complicated further by the present or proposed transmountain diversions from the Colorado basin. In view of the large diversion from the lower Colorado to the Los Angeles basin, full consideration of basin water strategy in the western Mississippi basin would require attention to Colorado and Southern California needs, and those now are linked with the Columbia in tentative schemes for later diversions.

Looking back over the growth of the basin-wide idea in the United States, it is notable that the earlier examples of action were intrastate-the Miami, Muskingum, Wisconsin, and Central Valley of California. On the other hand, the large and dramatic examples of both multiple-purpose and basin-wide planning came in interstate situations, where strong leadership and participation by the federal government was necessary to organization and financing.

The discussion, thus far, has dealt chiefly with the evolution and demonstration of individual ideas comprising the concept of integrated river basin development. Some of the demonstrations were not associated with other parts of the concept: thus, the Miami was strictly single-purpose; and Hoover Dam, while multiplepurpose, was not, in its first years, linked with a comprehensive basin plan. The degree to which the complete concept has been translated into action is revealed, in

${ }^{80}$ And even the Mississippi is not entirely free from international complications. A tributary of the Missouri, the Milk River, drains both Canadian and United States territory and is the subject of an international agreement. 
part, by Table I and Figure 3. These show some major river basin development schemes constructed or under construction, as of 1957 . Where a basin-wide plan has been projected but work is presently limited to only one project, as in the case of the Zambesi and the Volta, the entire area is shown. Where one project has been constructed without being linked with a basin plan, it is omitted. The Niger Office, responsible for the inland delta, is a borderline case. Systems of single-purpose projects also are omitted.

Table I-Representattve Integrated River Basin Development Programs

\begin{tabular}{|c|c|c|c|}
\hline Basin & $\begin{array}{l}\text { Area } \\
\text { (Sq. Mi.) }\end{array}$ & $\begin{array}{l}\text { Major purposes } \\
\text { A Fertilizer manu- } \\
\text { facture } \\
\text { F Flood control } \\
\text { I Irrigation } \\
\text { M Manufacturing } \\
\text { N Navigation } \\
\text { P Electric power } \\
\text { S Soil conservation } \\
\text { T Forestry }\end{array}$ & $\begin{array}{l}\text { (Dams are storage unless otherwise } \\
\text { designated. Installed hydroelectric } \\
\text { capacity is shown in kilowatts.) }\end{array}$ \\
\hline
\end{tabular}

Columbia partial F-I-N-P

(United 219,500

States)

Damodar

(India)

Huai

(China) 67,200 F-I-N-P

Kitakami

(Japan)

3,950

F-I-P

Oum er Rbia

(Morocco)

$13,500 \quad$ I-P

Rhône
(France)
I6 dams (4,500,000 KW). 4I nonfederal hydroelectic plants. Irrigation diversion dams and canals. At least I5 other dams planned. Navigation works.

7 dams underway (200,000 $\mathrm{KW}$ ). Navigation channel. Land treatment. Industrial plant.

I5 detention dams. 7 storage dams. Levees and drainage works. Irrigation works. Locks. 2 hydroelectric plants $(35,000 \mathrm{KW})$.

7 dams ( $172,000 \mathrm{KW})$. Irrigation works.

6 dams and hydroelectric plants ( $158,000 \mathrm{KW})$. Irrigation works and improvement. Diversion dams.

2 dams and one other hydroelectric plant (700,000 KW). Locks and canals. II other dams and hydroelectric plants planned. 
182

Tennessee

United States $\begin{array}{lrr}\text { Tigris- } & \text { partial } & \text { F-I-P-N } \\ \text { Euphrates } & \text { I92,I93 } & \\ \quad \text { (Iraq) } & & \end{array}$

Volga-Don $\quad 695,700 \quad$ I-N-P
Law and Contemporary Problems

$40,670 \quad$ F-N-P-A-S-T
27 dams $(2,600,000 \mathrm{KW})$. Locks. Fertilizer plant. Fuel electric plants. Agricultural demonstra- tion.

4 dams $(700,000 \mathrm{KW}) .7$ diversion dams. 7 others planned. Land drainage and irrigation. Locks.

3 major dams $(3,860,000 \mathrm{KW})$. Locks. Navigation canals. 3 other hydroelectric plants. 2 others planned. Irrigation works.

It is apparent from Figure 3 that the chief areas in which systems of multiplepurpose projects are under way lie either wholly within one country or are restricted to that part of the drainage located within one country. In terms of size of drainage area, the larger areas are located in Brazil (the San Francisco), China (the Huai and Yellow), India (the Damodar and Mahanadi), the Soviet Union (the Amu-Darya, Dneiper, Don, and Volga), and the United States (the Central Valley of California, Arkansas-White-Red, Columbia, Colorado, Missouri, Rio Grande, Savannah, St. Lawrence, Tennessee, and upper Ohio). Smaller complete drainages or subbasıns include the Snowy Mountains-Murray scheme in Australia, the Ruhr-Emscher-Lippe in Germany, the Kitakami in Japan, the Papaloapan in Mexico, the Oum er Rbia in Morocco, and lesser streams in Puerto Rico and the Philippines.

The international streams which are being developed within only one country are the Rhône in France, the Zambesi in the Central African Federation, the Volta in the Gold Coast, and the Tigris-Euphrates in Iraq. No major international stream is receiving completely integrated treatment across frontiers. Perhaps the nearest approaches are on the Columbia River, through the International Joint Commission, and on the Rio Grande, through the International Boundary Commission. Parts of the Indus system are receiving attention on both sides of the India-Pakistan border, without agreement as to the precise terms of regulation and use, and there is a loose agreement affecting Nile waters.

In mapping the more important schemes, two criteria were used: they must involve systems of multiple-purpose projects, and they must involve the entire drainage basin or subbasin within the country of operations.

\section{V}

\section{Aspirations and Stirrings}

Spread of the essential ideas in unified river basin development has been outlined in terms of action taken across the continents. It might also be perceived, though less precisely, in the aspirations which reflect themselves in citizen, national, and international plans commanding public attention, but not yet channeled into con- 
struction works. These would include some basins, such as the Connecticut, where plans have been made, but in which unified action has not yet been launched, and other basins where discussion is far ahead of any detailed planning, as in the upper Amazon basin.

The Nile basin is still in the preliminary stage: notwithstanding the waters agreement, plans for the Aswan High Dam do not take account of possible future needs and regulatory action in the Sudan, Ethiopia, and Tanganyika sections of the basin. Likewise, the Jordan River has been studied repeatedly, without arriving at a satisfactory agreement. The Rhine River, though the subject of Dutch-German and German-French-Swiss negotiations, has not been subjected to a single, unified plan. ${ }^{81}$ Both official and citizens groups now are working to perfect more precise arrangements for handling the Rhine waters in flood and drought. Danubian cooperation embraces only a portion of that basin. Congo planning for integrated land and water transportation facilities is well advanced without comprising a system of water regulatory works for other purposes. There are large new storage projects in the upper Ganges and river channel improvement plans for the Mekong that may, in time, evolve into unified systems of projects. An agreement concerning the Amur has been negotiated during the past year.

\section{VI}

\section{Stgnificance of the Concept in Practice}

Reviewing the evolving ideas of the past sixty years as they now find expression in landscape and livelihood and aspiration, a few aspects stand out:

The idea of multiple-purpose water storage, while once considered of doubtful practical value, now is firmly established in present construction technology.

The idea of unified basin plans has moved slowly from theoretical acceptance to practical application: in the United States, first slowly in intrastate drainages, then quickly in the more challenging interstate drainages, but, thus far, across no international boundary to cover a complete basin.

The idea of comprehensive regional development has gained gradually in application, the vague vision of regional growth being more persistent than efforts to define or measure it.

Associated with the second of these ideas, the idea of land improvement integrated with water use and control has remained in popularity, but has been applied only rarely in genuine plans and programs.

Spreading rapidly in the realm of public discussion, the idea of unified administration has skipped from the TVA and the Rhône to a few other places, but has inspired more controversy than imitation.

Throughout the period, there has been conspicuous lack of careful appraisal of the work accomplished. A tool capturing imaginative support, as this one does,

${ }^{81}$ See, Wehle, International Administration of European Inland Waterways, 40 AM. J. INT'L L. I00 (1946). 
deserves penetrating assessment, and such examination has been largely absent. For every hundred studies of what might or should be done with a river system, there is hardly one that deals with the results. In so far as the results are physical, some may be measured readily-kilowatts of power produced, cubic feet of water delivered, inches of reduction in peak flow, acres irrigated. Some physical results have been touched only lightly, as, for example, effects of water storage and mixing on downstream erosion and water quality.

The social results are perceived dimly; there are only the roughest gauges of the effects of river works upon economic growth and community stability or change. Little basis exists for comparing the effectiveness of one multiple-purpose plan with another for the same basin or with an alternate method of fostering social change. Thus far, there has been no genuinely searching assessment of the full impact of the TVA operations, and it is needed. ${ }^{82}$ Yet, if it were to be undertaken, it would require as a first step a sharpening of devices for measuring construction efficiency, economic growth, and cultural advancement. Strict adherence to the ideas of multiple-use regulation for entire basins leads inevitably to confrontation of regional aims and social processes.

${ }^{82}$ McKinley, TVA Management in the Perspective of Two Decades, 16 PuB. ADMIN. REv. 109 (1955); Fisher, Resource Problems and the Social Sciences, in Resources for the Future, AnN. Rep. 15 (1956). 


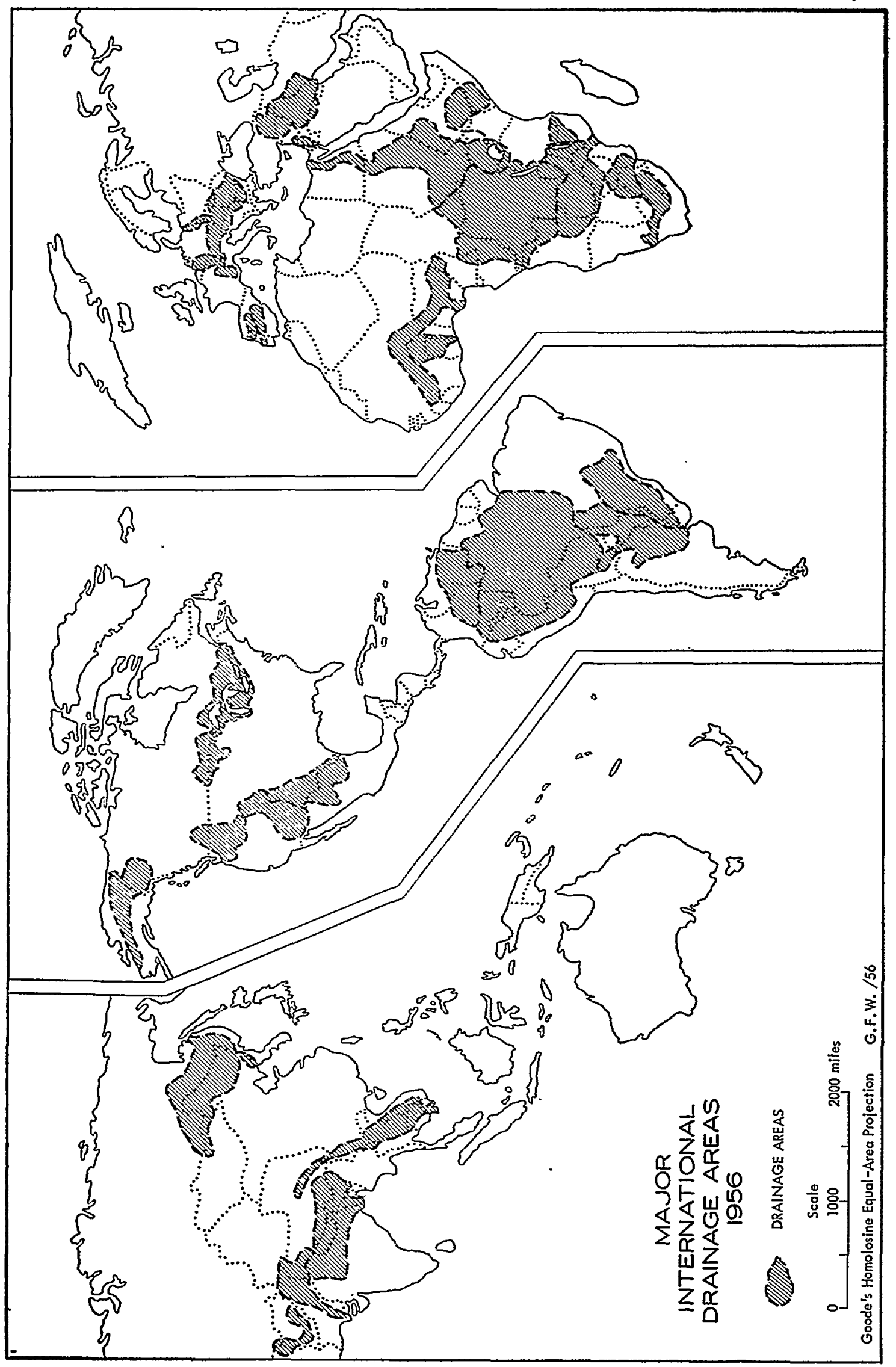




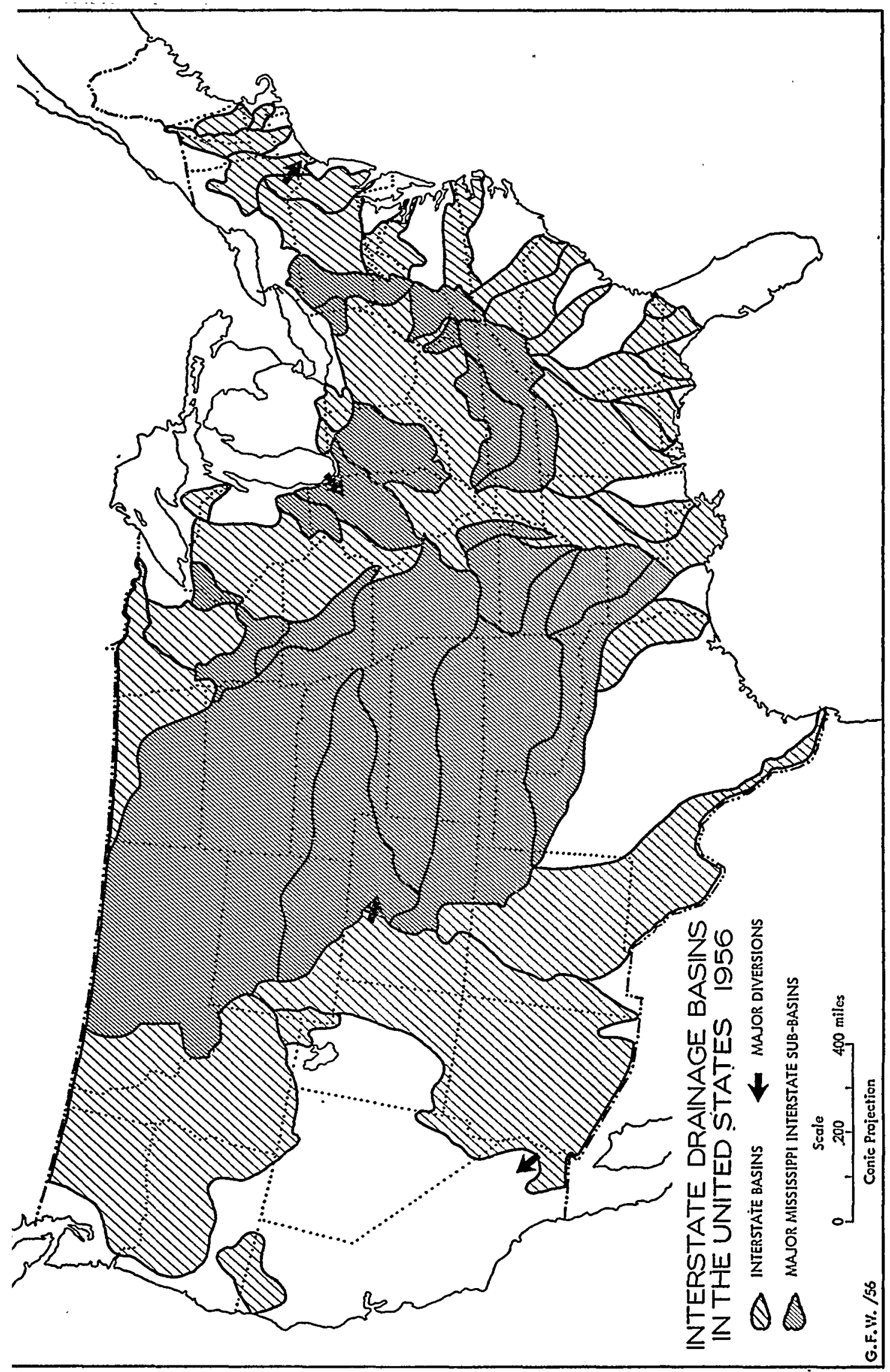




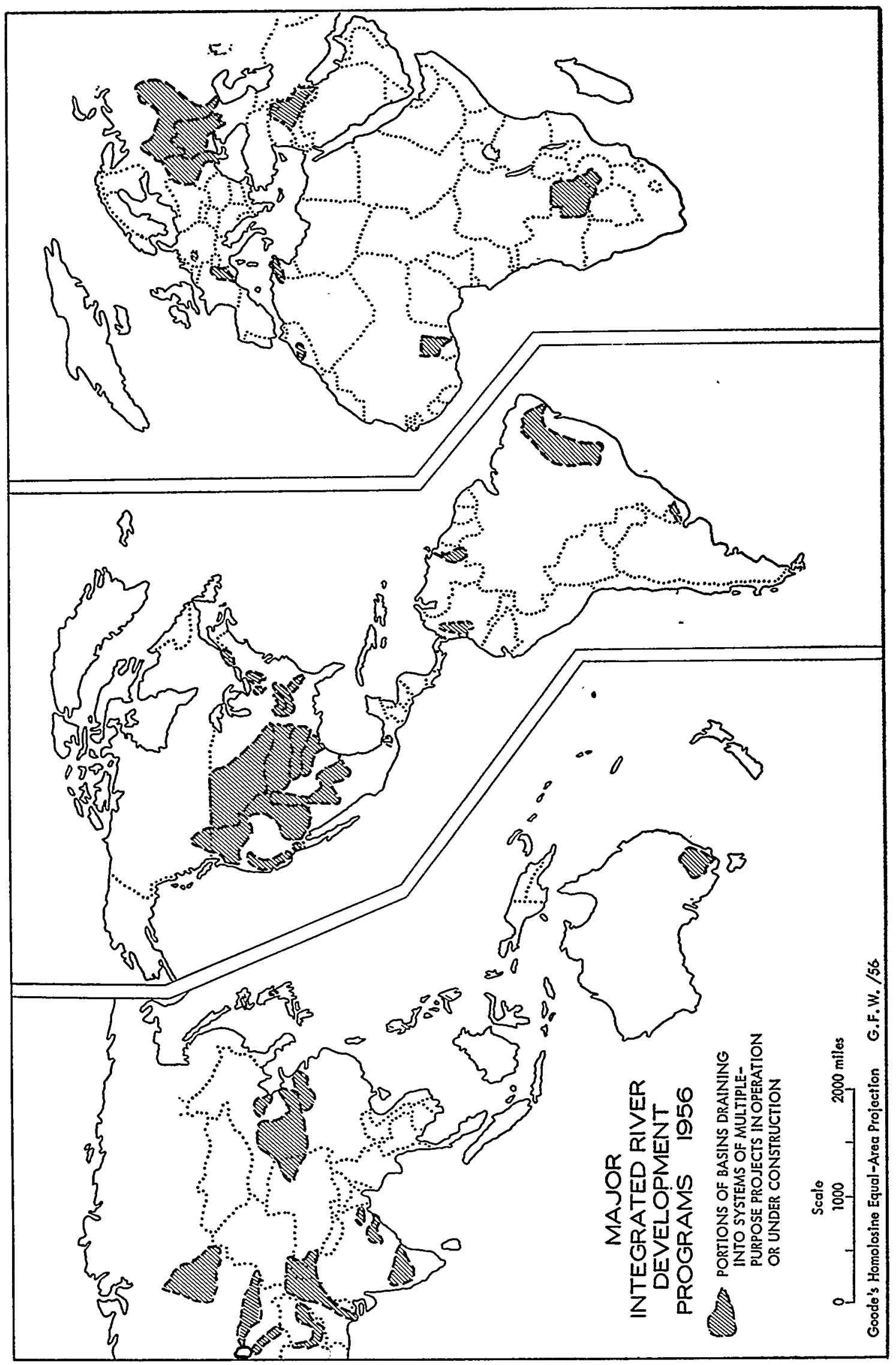

